\title{
Evaluation of Carbon Credits Earned by a Solar Energy Park in Indian Conditions
}

\author{
Prabhakant and G. N. Tiwari*
}

\author{
Center for Energy Studies, Indian Institute of Technology Delhi, Haus Khas, New Delhi 1100 16, India
}

\begin{abstract}
This paper presents an analysis of carbon credit earning by the Solar Energy Park (SEP) at I.I.T. Delhi, New Delhi, India. The solar energy park consists of a mud house, various hybrid photovoltaic thermal (PV/T) systems with stand alone photovoltaic (SAPV) power supply. The analysis is based on experimental and theoretical annual performance of each system. The life cycle cost analysis is based on the annual performance and carbon credit earning of the Solar Energy Park. The computation of the carbon credit earned by the Solar Energy Park as per the norms of the Kyoto Protocol under New Delhi climate condition has also been carried out. Estimation of carbon credits, which will accrue to the nation if one such Solar Energy Park is built in each district/ block/Village in the country, has also been evaluated. 'Return on the investment' analysis on the basis of the life cycle cost analysis has also been made. It is seen that the cost of power generated by the SAPV system (USD $0.14 / \mathrm{kWh}$, USD 0.125 , USD 0.116 for life cycle of 30,40 and 50 years respectively) will be cheaper than the cost of power generated by conventional systems. It may be due to the improved technology and the economy of scale.
\end{abstract}

Keywords: Carbon credits, photovoltaic thermal hybrid solar systems, return on capital of solar systems, solar energy.

\section{INTRODUCTION}

Energy consumption of a country is one of the indicators of its socio economic development. Per capita electricity consumption of India is one of the lowest in the world. Also, India will exhaust its oil reserves in 22 years, its gas reserves in 30 years and its coal reserves in 80 years [1]. More alarming, the coal reserves might disappear in less than 40 years if India continues to grow at $8 \%$ a year [1].

Solar PV Systems are one of the most promising future sources of energy. A group of solar cells connected in series, packed with ethyl vinyl acetate (EVC) (transparent adhesive) and insulated from the back side is known as a PV Module. The top surface of the cells is coated with an antireflective transparent coating. PV modules, connected in series, parallel or combination of both are known as PV array.

In India the cost of electricity generated by Solar PV cells comes to USD $0.154 / \mathrm{KWh}$ (Rs $6.8 / \mathrm{kWh}$ ), globally and the capital cost of installing a Solar PV system comes to USD 6187-8937/kWp [2] and USD 8172/kWp [3]. Prakash et al. [4] have estimated that solar photovoltaic power cost is expected to decrease by 50 per cent in the next 15-20 years. Both the capital cost as well as the cost of electricity generated is likely to go down substantially with
a). Economy of scale
b). Advancement in technology and
c). Carbon credits earned by such PV plants (as per Kyoto Protocol) are taken into account.

\footnotetext{
*Address correspondence to this author at the Centre for Energy Studies, I.I.T. Delhi, 110016, India; Tel: +91 11 26591258; Fax: +91 11 26581121/ 26862037; E-mail: gntiwari@ces.iitd.ernet.in
}

Secondly stand alone PV systems are well suited for Indian conditions. These systems do not require sophisticated grid synchronization equipments and systems. The electrical energy generated is directly used in running the electrical loads and the balance is stored in battery banks. These batteries along with an inverter (a device to convert direct current into $\mathrm{AC}$ ) are used to run the electrical loads during night/ off sun shine period.

Carbon Credit Trading (Emission Trading) is an administrative approach used to control pollution by providing economic incentives for achieving reductions in the emissions of pollutants. The development of a carbon project that provides a reduction in Greenhouse Gas emissions is a way by which participating entities may generate tradable carbon credits. Carbon credits are a tradable permit scheme. A credit gives the owner the right to emit one ton of carbon dioxide. International treaties such as the Kyoto Protocol set quotas on the amount of greenhouse gases which a country can produce. Countries, in turn, set quotas on the emissions of businesses. Businesses that are over their quotas must buy carbon credits for their excess emissions, while businesses that are below their quota can sell their remaining credits. The sale and purchase of credits empowers a business for which reduction of emissions would be expensive or prohibitive to pay another business to continue operations. This minimizes the quota's impact on individual business, while still meeting the quota on national scale. Credits can be exchanged between businesses or bought and sold in international markets at the prevailing market price. There are currently two exchanges for carbon credits: the Chicago Climate Exchange and the European Climate Exchange. In the year 2005, 375 million tons of carbon dioxide equivalents $\left(\mathrm{tCO}_{2} \mathrm{e}\right)$ were transacted at a value of USD 4.55 billion with average price of USD 14.52 (1 credit $\left.=1 \mathrm{tCO}_{2} \mathrm{e}\right)$. In the first three months of 2006, 
average reported price of carbon dioxide equivalent was USD 22.99 per ton. European and Japanese Companies were the major buyers and China was the major seller of the carbon credits in 2005-06. Demand of carbon credits continued to soar in 2006-07 resulting in increase in the traded rate of carbon credits. Present market rate is fluctuating at $€$ 20-22 (USD 27.5-30.25) in the European Climate Exchange [5].

In this paper, the life cycle cost analysis of a stand alone solar photovoltaic system has been also carried out, considering the effect of $\mathrm{CO}_{2}$ credit earned.

\section{PROBLEM IDENTIFICATION}

Estimation of carbon credits likely to be earned by the Solar Energy Park (SEP) will help in estimating the cost of production of electricity by the various systems. It will also help estimating the return on capital of such systems. Carbon credits earned is directly deductible from the cost of electricity produced.

Cost of installing at least one "Solar Energy Park" in each district, in each village having population more than 1000 and corresponding carbon Credits which the country is likely to earn by doing so have also been estimated.

\section{SOLAR ENERGY PARK}

Solar Energy Park is located in the campus of I.I.T. New Delhi $\left(29^{\circ} 35^{\prime} \mathrm{N}, 77^{\circ} 12^{\prime} \mathrm{E}\right)$. It is spread over an area of $23 \mathrm{~m}$ $\times 42 \mathrm{~m}$. It has built-up area (Mud House) of $11 \mathrm{~m} \times 13 \mathrm{~m}$. The aerial view of solar energy park at IIT Delhi has been shown in Fig. (1). The stand alone PV system, various PV/T solar systems have also been marked in the same figure. A brief description of the various systems follows:

\subsection{Photovoltaic Systems}

The stand alone photovoltaic system (SAPV), see Fig. (1), consists of two arrays of PV module; the first array is of CEL make and has 32 modules and the second array is of SIEMENS make and is having 34 modules. These are integrated with the electrical load of the Solar Energy Park (SEP) including that of the "Mud house". The direct current produced by the SAPV power system is converted into standard $220 \mathrm{~V}$ AC supply by an inverter; the DC produced is also used to charge the battery bank of the back up power system When there is no solar intensity (cloudy sky or during night) backup power system takes over the electrical load. The SAPV system supplies uninterrupted power to all the electrical appliances fitted in the Solar Energy Park (SEP) including that in the Mud House. The first array is rated at 1.12 kilowatt peak power out put rating. The second array has 2.4 kilowatt peak power out put rating. The battery bank has the specification; 48 Volt / 360 Ampere Hour (Ah), Tubular type; 6 Volt / 180 Ampere Hour batteries have been used in the battery bank. The inverter is of 3 KVA rating. The inverter has an efficiency around 90 percent.

\subsection{Mud House (MH)}

"MUD HOUSE" is a six room building, built of traditional building material, in Indian Villages. The lay out plan has been shown in Fig. (2). It is a natural conditioned vaulted or curved roof structure for composite climate, made of three-layered $23 \mathrm{~cm}$ thick roof. The inside layer is 7 centimeter thick brick, middle layer is of Mud and is $12 \mathrm{~cm}$ thick and the outer layer consists of $4 \mathrm{~cm}$ thick brick tiles. Walls are having two layers. Outer layer is $12 \mathrm{~cm}$ thick and is made of mud. The inner layer is of brick having $7 \mathrm{~cm}$ thickness. Mud forms 70 percent of the building material hence the name "Mud house". There is a provision of day-lighting in the

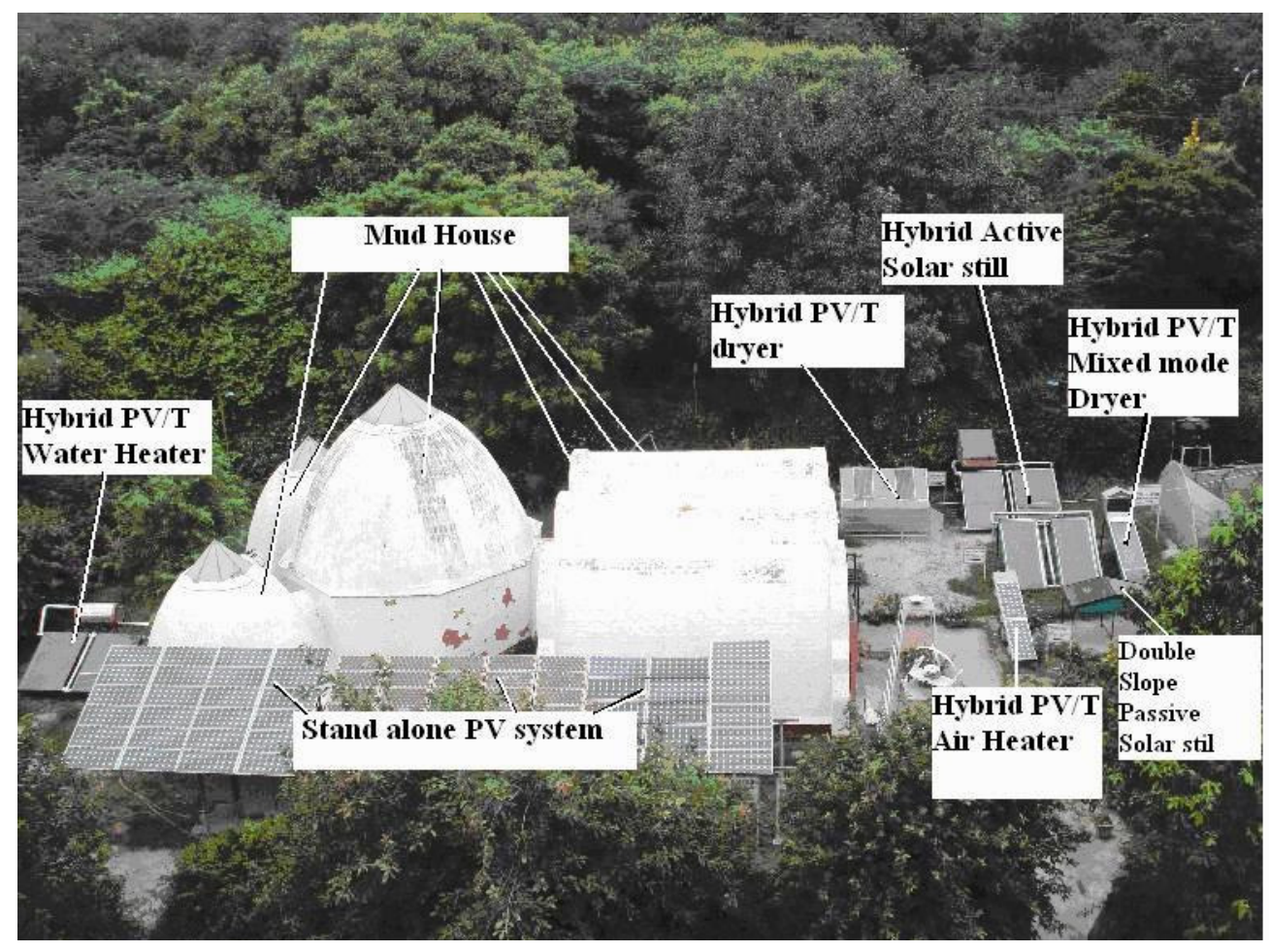

Fig. (1). Aerial view of solar systems at Solar Energy Park, IIT Delhi. 
central hall of Mud house. The variation in room temperature is attenuated as compared to ambient air temperature fluctuations because of thick walls and roof of Mud house and high thermal heat capacity and low heat conductivity of Mud. The maximum monthly heating and cooling potential are 152.7 $\mathrm{kWh}$ in February and $111.1 \mathrm{kWh}$ in June respectively for New Delhi climatic condition [4]. The Mud house is integrated with Earth air heat exchanger. Earth air heat exchanger has a PVC pipe of $6 \mathrm{~cm}$ diameter and $60 \mathrm{~m}$ length buried $1.5 \mathrm{~m}$ underground and a blower of capacity $158.8 \mathrm{~kg}$ per hour for thermal comfort round the year. It is observed that the mud house can maintain constant $\left(14^{\circ} \mathrm{C}-16^{\circ} \mathrm{C}\right)$ temperature inside the room during winters. Under natural circulation mode, during summer, the inside room air temperature can be maintained between $32^{\circ} \mathrm{C}$ to $35^{\circ} \mathrm{C}$ when the outside ambient air temperature reaches $48^{\circ} \mathrm{C}$. Using Earth air heat exchanger, room air temperature can be maintained from 28 to $30^{\circ} \mathrm{C}$ in summer season. Electrical appliances installed in the mud house are tabulated in Table 1.

The yearly heating/cooling potential in the Mud house in terms of energy and exergy has been calculated by thermal model based on quasi-steady state condition. The result is based on monthly heating/cooling potential. The computation for monthly energy saving has been carried out by using basic energy balance equations in a quasi-steady state condition to determine the six room temperature. There is about 5$10 \%$ uncertainty errors between theoretical and measured value of room air temperatures [4].

\subsection{Green House}

Ultraviolet (UV) resistant plastic sheet has been used for fabrication of greenhouse which can be replaced after every 3-4 years. The materials used for fabrication of the structure of the greenhouse are aluminum and galvanized iron pipes. This can have the life time of about 20-30 years.

\subsubsection{Hybrid Greenhouse Dryer (HPVTG)}

It is a hybrid Photovoltaic integrated roof type even span greenhouse dryer. It is used for drying of crop produce. The dryer can operate in two modes, forced as well as natural circulation mode. The dryer has a floor area of $6.5 \mathrm{~m}^{2}$ with $1.80 \mathrm{~m}$ central height. Side walls are $1.05 \mathrm{~m}$ high. Its roof

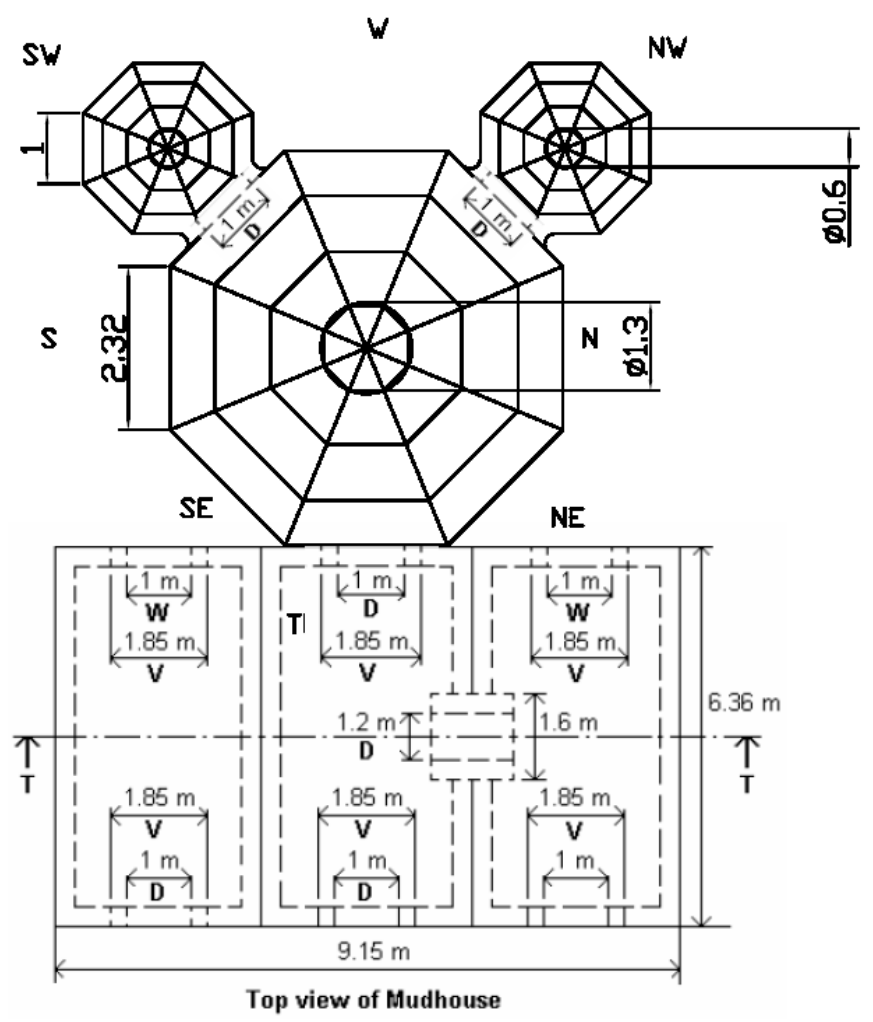

Fig. (2). Layout of mud house.

Table 1. Daily Total Load in Solar Energy Park

\begin{tabular}{|c|c|c|c|c|c|}
\hline S. No. & Name of Device & Quantity & $\begin{array}{c}\text { Electrical } \\
\text { Rating Watts }\end{array}$ & $\begin{array}{l}\text { Number of Hours in } \\
\text { Operation/Day }\end{array}$ & $\begin{array}{l}\text { Total Energy Consumed } \\
\text { (W/day) }\end{array}$ \\
\hline 1 & Tube lights & 6 & 60 & 4 & 1440 \\
\hline 2 & Fans & 4 & 60 & 4 & 960 \\
\hline 3 & Computer & 5 & 450 & $\begin{array}{l}6 \text { hrs ( } 3 \text { computers }) \text { and } \\
24 \text { hrs ( } 2 \text { computers })\end{array}$ & 9900 \\
\hline 4 & Fridge & 1 & 100 & 24 & 2400 \\
\hline 5 & Water Pump & 1 & 350 & 2 & 700 \\
\hline 6 & Hybrid Photovoltaic/thermal Water Heater & 1 & 60 & 4 & 240 \\
\hline 7 & Evacuated Tubular water heater & 1 & & & \\
\hline 8 & $\begin{array}{l}\text { PV/ Thermal Hybrid system Hybrid photovoltaic } \\
\text { /thermal air heater system }\end{array}$ & 2 & 24 & 12 & 576 \\
\hline 9 & Aquaculture Greenhouse & 1 & 20 & 24 & 480 \\
\hline 10 & Greenhouse & & & & \\
\hline 11 & Active solar still & & 60 & 8 & 480 \\
\hline 12 & Hybrid Photovoltaic/Thermal Greenhouse dryer & 1 & 580 & 8 & 4640 \\
\hline 13 & Street Lights & 12 & 18 & 4 & 864 \\
\hline \multirow[t]{2}{*}{14} & Air dryer & 1 & 35 & 24 & 840 \\
\hline & & & & & 23520 (W/day) \\
\hline
\end{tabular}


has a slope of 30 degree to receive the maximum solar radiation annually [6]. Two SIEMENS make Photovoltaic modules of 75 watt peak each, glass to glass were used for thermal heating of greenhouse environment and to provide DC electrical power to operate a DC exhaust fan under forced mode condition for removal of moisture from the dryer. The dryer has three-tier system, upper high temperature zone, middle medium temperature zone and bottom low temperature zone for different types of food products to be dried. The position of hybrid greenhouse dryer has been shown in Fig. (1) [6].

The grapes were dried in the dryer. It took about 15 days to dry the grapes. The annual thermal energy and exergy were evaluated by assuming 300 clear days which can be used by the hybrid dryer for 20 times drying of grapes.

\subsubsection{Hybrid Greenhouse Dryer for Cultivation (HPVTGD)}

The hybrid PV integrated greenhouse with an effective floor area of $20 \mathrm{~m}^{2}$ with central and side walls of height of $3 \mathrm{~m}$ and $2 \mathrm{~m}$ respectively is considered for the present study. There are 13 SIEMENS make Photovoltaic modules of 75 watt peak each which is integrated with the green house as shown in Fig. (3) [7]. The inclination of the PV module is $45^{\circ}$ to receive maximum solar radiation in the winter for production of electricity as well as thermal energy to heat the inside greenhouse air. The hybrid greenhouse can also be used in the summer as a dryer on large scale. The hybrid greenhouse has facilities of various heating and cooling techniques such as roof vent, forced mode by fans, evaporative cooling and earth air heat exchanger. All electrical gadgets/instruments are operated by electricity produced by PV modules. So the net electricity produced can be used for other purposes.

\subsection{Hybrid Photovoltaic / Thermal Air Heater (HPVTAC)}

The system consists of two Photovoltaic modules, each having $0.605 \mathrm{~m}^{2}$ area fitted to wooden air duct [8], 2. Two DC fans have been fitted to the air duct to suck air. The fans cause the ambient air to flow across the lower (inside) surface of the photo-voltaic modules. The surface area of the duct is $0.045 \mathrm{~m}^{2}$. Air flow velocity with single D.C. fan is approximately $1.5 \mathrm{~m} / \mathrm{s}$ and that with two D.C. fans is approximately $3 \mathrm{~m} / \mathrm{s}$. The fans have power rating of $24 \mathrm{~W}$. Rise in outlet air temperature of 3 to $6^{\circ} \mathrm{C}$ in single fan mode and 2 to $4^{\circ} \mathrm{C}$ in double fan mode have been observed.

\subsection{Solar Still}

In the Solar Energy Park, there are passive and active solar stills to be used for purification of under ground brackish water (salinity of about 5000-10000 ppm) for drinking purposes [9]. The distilled water has the salinity of about 8$10 \mathrm{ppm}$. The drinking water can have the salinity of about $500 \mathrm{ppm}$. So the yield (distilled water) can be further enhanced by mixing brackish water to raise the salinity from 10 ppm to $500 \mathrm{ppm}$.

\subsubsection{Passive Solar Still (PSD)}

There are five single and three double slope solar stills with an effective area of $11 \mathrm{~m}^{2}$. The annual average yield per $\mathrm{m}^{2}$ per day is 2 liters for 300 clear days, which yield about $600 \mathrm{~L}$ per year. The glass and fiber re-enforced plastic materials have been used for condensing cover and body of solar stills. The single slope solar still has the south facing orientation while the double slope still has been oriented in the east and west direction to receive the maximum yearly solar radiation. The average annual operating temperature of water in the basin is about $45-50^{\circ} \mathrm{C}$. One can make the arrangements for rain harvesting in the double slope solar still which

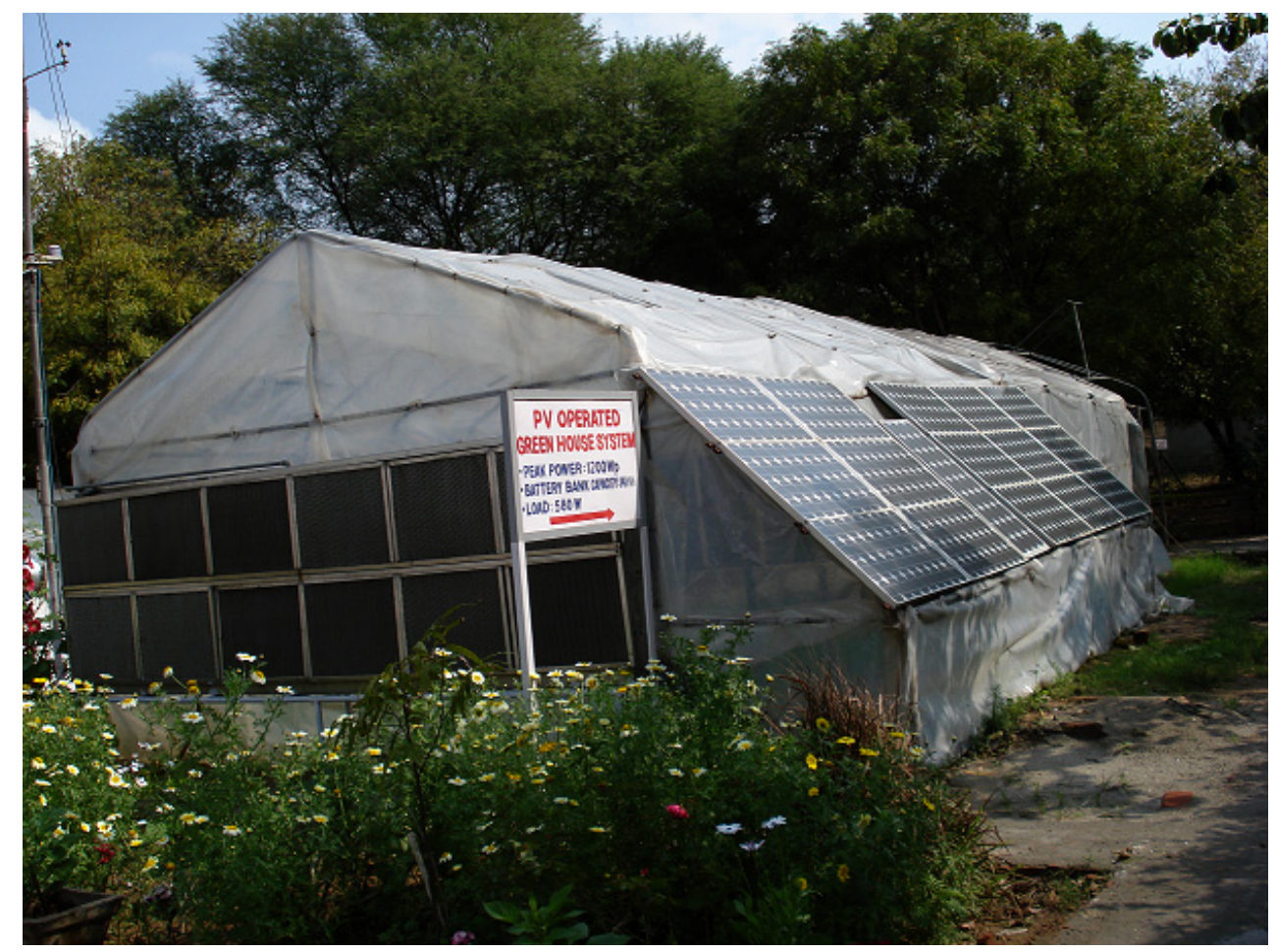

Fig. (3). PV integrated greenhouse system with evaporative cooling. 


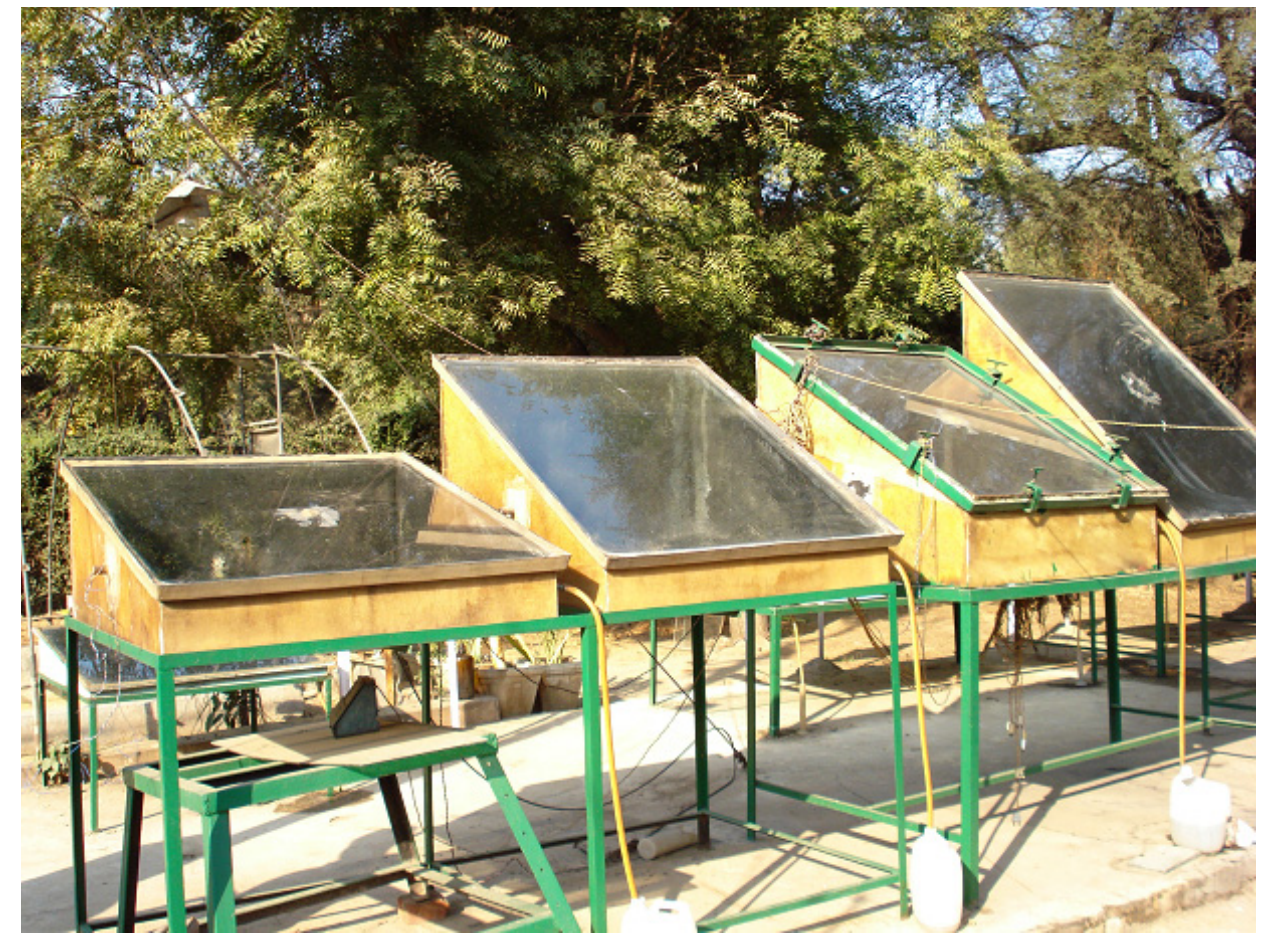

Fig. (4). Passive solar distillation system at different inclination of condensing cover.

will enhance the annual yield. The photograph of various passive solar still is shown in Fig. (4).

\subsubsection{Active Solar Still (ASD)}

There is an active solar still having two flat plate collectors connected in series, each having an area of $2 \mathrm{~m}^{2}$ (total area of flat plate collector is $4 \mathrm{~m}^{2}$ ), coupled to single slope solar still with an effective area of $1 \mathrm{~m}^{2}$. The glass condensing cover and the flat plate collectors are inclined at 45 degree to the horizontal to receive maximum solar radiation in winters. The PV module is integrated at the bottom of the first collector and generates electricity to operate the water pump. The water pump circulates the hot water between the collectors and the solar still. The average annual operating temperature of the water in the basin of active solar still is about $55-65^{\circ} \mathrm{C}$. The annual yield per $\mathrm{m}^{2}$ per day is 5 liters 300 clear days, which yield about $1500 \mathrm{~L}$ per year. There is one active solar still in the Solar Energy Park at IIT Delhi.

\subsection{Water Pump (WP)}

The water resource is available for 24 hours round the year but sometimes no water is available in the IIT Campus. This is due to its operation of submersible water pump of $0.35 \mathrm{~kW}$ by using Photovoltaics operated. The pump is located underground at a depth of 135 feet and has flow rate of $2.5 \mathrm{~kg} / \mathrm{s}, 31.4 \mathrm{~m} / \mathrm{s}$ velocity from pipe of $1 \mathrm{~cm}$ diameter. The water so available is used for the maintenance of the energy park activities.

\subsection{Hybrid PV/T Water Heater (HPVTWC)}

Hybrid photovoltaic/thermal water heater with a storage capacity of 200 liters has been installed. A DC pump is operated for its operation in the forced mode. In this case, two flat plate collectors are connected in series, each having an area of $2 \mathrm{~m}^{2}$ (total area of flat plate collector is $4 \mathrm{~m}^{2}$ ). The

SIEMENS make PV module is integrated at the bottom of the first collector and generates electricity to operate the water pump between storage tank and collectors. The photograph of hybrid water heater has been shown in Fig. (1).

The annual thermal energy available is about $2720 \mathrm{kWh}$ [10].

\section{NUMERICAL COMPUTATIONS}

\subsection{Effect of Solar Intensity and Number of Clear Days}

Power produced by the SAPV system is proportional to solar intensity and to number of clear days in a year. Power produced, carbon credits earned and return on capital has been calculated and given in Table 4 assuming the solar intensity to be $700 \mathrm{~W} / \mathrm{m}^{2}, 500 \mathrm{~W} / \mathrm{m}^{2}$ and $350 \mathrm{~W} / \mathrm{m}^{2}$ and number of clear days in a year to be 300, 250 and 200. Power output of the SAPV system varies with variation in solar intensity. Prakash et al. [4] have computed the efficiency of the solar PV modules on a typical day (Sept. 11, 2006) used in the solar energy park at $6.08 \%$ for CEL module and $12.52 \%$ for SIEMENS module. Though the efficiency of the cells will vary with variation in ambient temperature, inclination of PV modules, for calculation purpose it has been taken as the average efficiency of the PV modules installed in the solar energy park.

Power output of the SAPV system is computed as under:

Area of single CEL module

Total number of CEL Modules

Total area of CEL modules

Area of single SIEMEN module

Total number of SIEMEN Modules

Total area of SIEMEN modules

$$
\begin{aligned}
& =0.4 \mathrm{~m}^{2} \\
& =32 \\
& =12.8 \mathrm{~m}^{2} \\
& =0.6 \mathrm{~m}^{2} \\
& =34 \\
& =20.4 \mathrm{~m}^{2}
\end{aligned}
$$




$$
\begin{array}{lr}
\text { Efficiency }(\eta) \text { of CEL module [4] } & =6.08 \% \\
\text { Efficiency }(\eta) \text { of SIEMEN module [4] } & =12.52 \% \\
\text { Power }=\eta_{C E L} \times I_{T} \times A_{C E L}+\eta_{\text {SIEMEN }} \times I_{T} \times A_{\text {SIEMEN }}
\end{array}
$$

where, $\mathrm{A}$ is the total area of the modules

If solar intensity is $700 \mathrm{~W} / \mathrm{m}^{2}$, then

$$
\begin{aligned}
\mathrm{P}_{\text {out }} & =0.0608 \times 700 \times 12.8+0.1252 \times 700 \times 20.4 \\
& =2332.624 \mathrm{~W}
\end{aligned}
$$

Presuming solar light is available for 12 hours a day, then Power produced by the SAPV system per day $=2332.624 \times$ $12=27991.5 \mathrm{Wh}=28 \mathrm{kWh}$

Assuming number of clear days in a year is 300 , the power produced by the SAPV system per annum $=28 \times 300$ $=8400 \mathrm{kWh}=8.4 \mathrm{MWh}$

\subsection{Carbon Credits Earned by Solar PV/T Systems}

Further, we have evaluated the overall annual thermal energy and exergy of each system on the basis of experimental and theoretical results. On the basis of validation we have observed that there are about 5-15\% estimated error between experimental and theoretical results for each system. The overall annual thermal energy and exergy of each system has been evaluated as follows:

(i) The annual net electrical energy in terms of $\mathrm{kWh}$ for each system has been evaluated on the basis of experimental observations by measuring the load current and voltage on an hourly basis for one clear day in each month. The equivalent overall thermal energy for annual net electrical energy is obtained as [11],

$\sum \dot{Q}_{\text {u, overall thermal }}=\frac{\sum \dot{Q}_{u, \text { electrical }}}{0.38}$

The 0.38 factor is the conversion factor for thermal power plant.

(ii) The annual exergy [12-14], of each system has been evaluated by
$\dot{E} x_{\text {thermal }}=\dot{Q}_{u, \text { annual }}\left[1-\frac{T_{\sin k}+273}{T_{\text {source }}+273}\right]$

$\mathrm{Q}_{\mathrm{u} \text {, annual }}$ is the annual thermal energy obtained in terms of $\mathrm{kWh}$ for each system.

The overall thermal energy for each system is the sum of

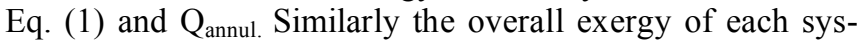
tem is the sum of Eq. (2) and net annual electrical energy obtained for each system if any.

The results of the overall thermal energy and exergy evaluated for each system has been shown in Fig. (5). It is observed that the overall annual thermal energy and exergy for the mud house and greenhouse are the largest. The overall annual thermal energy and exergy for Solar Energy Park is $106.5 \mathrm{MWh}$ and 2.692 $\mathrm{MWh}$. The mitigation of $\mathrm{CO}_{2}$ per year on the basis of thermal and exergy are 99.3 tons and 2.5 tons respectively.

If carbon dioxide emission reduction is at present being traded@USD 27.5/tons $\left(1\right.$ credit=1 tCO $\left.\mathrm{tCO}_{2} \mathrm{e}\right)$, then the carbon emission reduction by various solar systems (Figs. 1,5) in SEP is evaluated as follows:

$\mathrm{CO}_{2}$ credit earned by annual saving $=$ USD $99.3 \times 27.5=$ USD 2730.7 on the basis of energy $=$ USD $2.5 \times 27.5=$ USD 68.7 on the basis of exergy

\subsection{Carbon Credits Earned by SAPV System}

Total energy consumption in the solar energy park by the instruments/electrical gadgets in various system mentioned earlier are summarized in Table $\mathbf{1}$. It is evaluated that the total energy consumption is $23.52 \mathrm{kWh}$ per day.

The total installed capacity of the SAPV system is as follows:

a). 5 Frames with 32 number of CEL modules (each of $35 \mathrm{Wp}$ ), PV Power $=1120 \mathrm{Wp}$ and

b). 9 Frames with 34 number of SIEMEN modules ( each $75 \mathrm{Wp}$ ) $\mathrm{PV}$ power $=2250 \mathrm{Wp}$

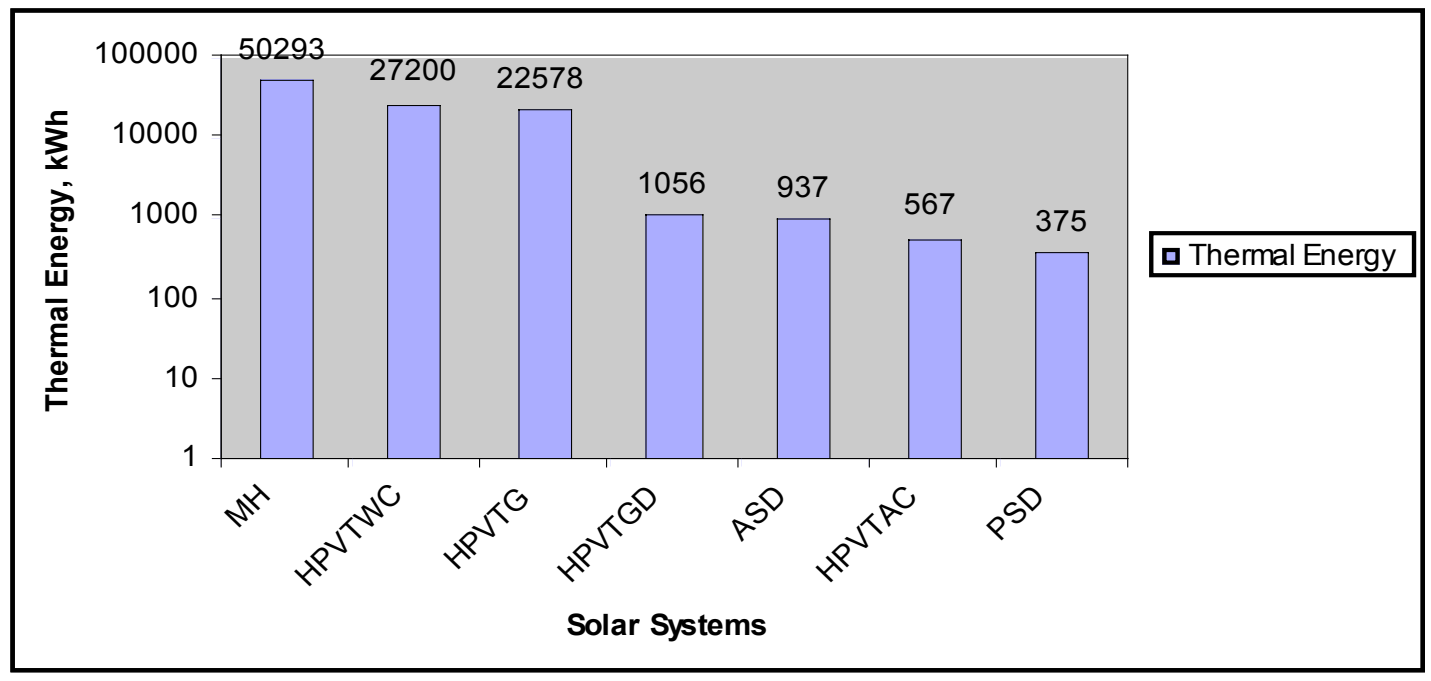

Fig. (5a). Annual thermal energy gain by various solar systems in solar energy park. 


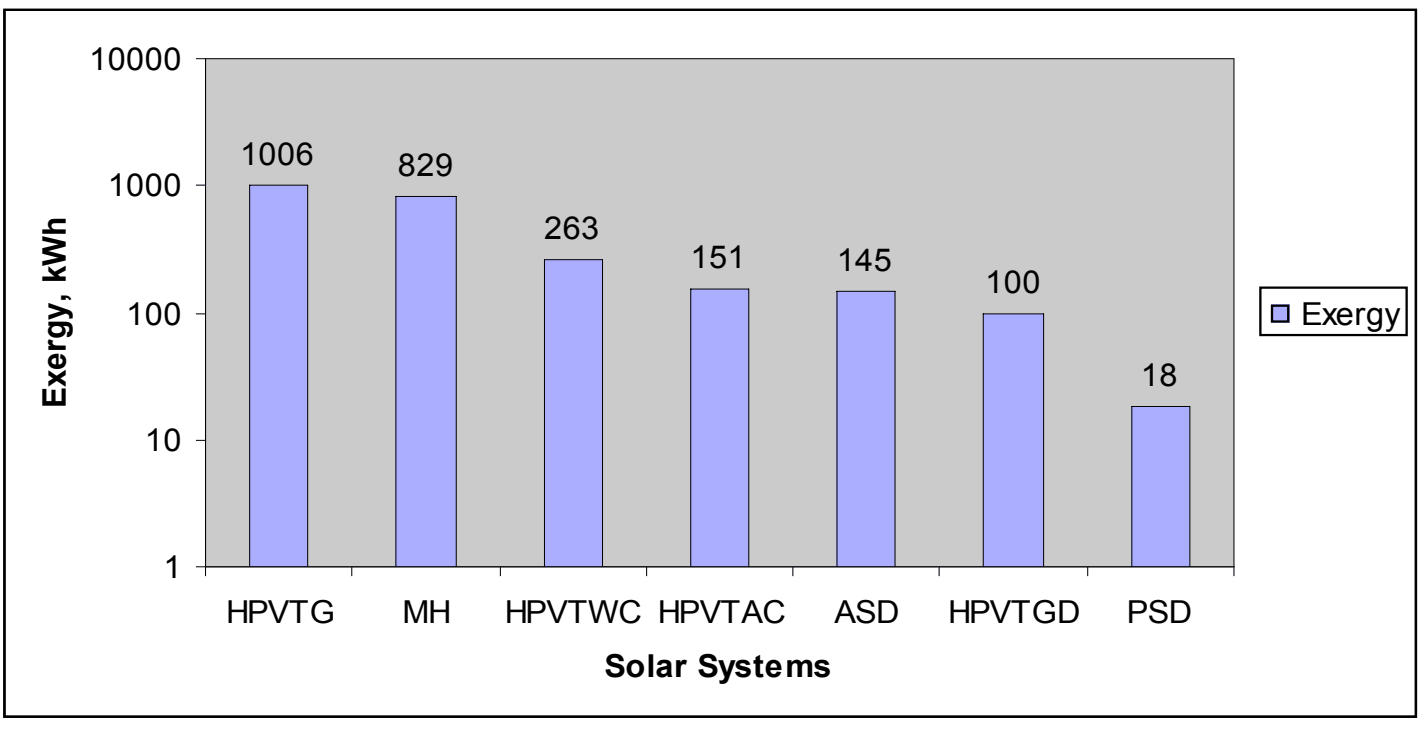

Fig. (5b). Annual exergy gain by various solar systems in solar energy park.

Total power produced $=(1120+2250) \mathrm{Wp}=3670 \mathrm{Wp}=$ $3.670 \mathrm{kWp}$

Assuming average twelve hours of sun shine per day, generally true for European condition all over the country,

Total Power Produced per day $=3670 \times 12$ (Eq. 4) $=$ $44040 \mathrm{Wh}=44.04 \mathrm{kWh}$

On an average there are 300 days of clear sky per annum, then

Total power produced per annum $=44.04$ (Eq. $5 \mathrm{a}) \times 300$ $\mathrm{kWh}=13212 \mathrm{kWh}=13.212 \mathrm{MWh}$

If the unit cost of electricity is Rs 5.5 , then, cost of energy produced per annum $=$ Rs $13212 \times 5.5=$ Rs 72666 (USD 1825.03)

If the sun shine hour for Indian condition is considered as six hour per day than cost of energy produced per annum $=$ Rs. $\frac{13212}{2}$ (Eq. 6) $\times 5.5=$ Rs 36333 (USD 908.3)

where the conversion of unit cost is $€ 1=$ Rs. 55 and Rs. 40 $=1$ USD at level of 2007 .

Carbon Dioxide reduction by Solar Photovoltaic Power Plants installed all over the world has been compiled by Denis Lenordic. Data for Carbon Dioxide emission reduction by the top 200 Solar Photovoltaic Power Plants are available [5]. The data available includes power produced per annum in MWh, annual carbon emission reduction. Average annual carbon emission reduction per MWh of electricity produced, for the top 100 solar voltaic power plants, data of electricity produced in MWh and emission reduction per annum for which are available, comes to 0.932 tons of carbon dioxide emission reduction per MWh of electricity produced.

Taking this average value of 0.932 tons of carbon dioxide emission reduction per MWh of electricity for the SAPV plant installed in the solar energy park,

$\mathrm{CO}_{2}$ (carbon) emission reduction $=13.212$ (Eq. 5b) $\times 0.932=$ $12.310545=12.31$ tons
As pointed out earlier, if carbon dioxide emission reduction is at present being traded @ USD 27.5/tons, then $\mathrm{CO}_{2}$ emission reduction by SAPV plant per annum $=12.31$ $($ Eq.7a) $\times 27.5=$ USD $338.5($ Rs 13479.5)

For six sun shine hour, $\mathrm{CO}_{2}$ emission reduction by SAPV plant $=\frac{338.5}{2}($ Eq. $7 \mathrm{~b})$

$=$ USD 169.2 per annum

\subsection{Carbon Credits Earned by Solar Energy Park}

$\mathrm{CO} 2$ credit earned by solar energy park (SEP) using (Eq.3) and (Eq. 7)

$=(68.7+338.5)=$ USD 407.2, for twelve sunshine hour

$=(68.7+169.2)=$ USD 238, for six sunshine hour

\subsection{Return on Capital Cost of SAPV}

In order to evaluate return on capital cost, the life of SAPV system has been considered from 30-50 years.

Assuming Life of the System $=30$ Years

$\mathrm{P}=$ Present Capital Cost $=$ USD 27412.4 (Table 2)

$\mathrm{P}_{\mathrm{u}}=$ Unit capital cost with help of Eq. (4) $=27412.4$ / $3.67=7469$ USD per $\mathrm{kWp}$

$\mathrm{S}=$ Salvage value of the system $=$ USD 687.5

The Batteries used in the power backup system have average life of 5 years and have salvage value of USD 12.49 1650

$\mathrm{P}_{\mathrm{B}}=$ Present battery cost $=1309.08-(12.49 \times 12)=\mathrm{USD}$

$\mathrm{P}_{\mathrm{Net}}=$ Net present cost $=19936.33+3036.95=\mathrm{USD}$ 31959.5

The return on capital can be evaluated as follows:

Return on capital $=\frac{\text { Cost of electrical power produced }+ \text { Carbon credit earned }}{\text { Net present } \cos t}$

By substituting the various values obtained from Eqs. (6b, 8 and 9), one has 


$$
\begin{aligned}
\text { Return on capital } & =\frac{1327+296.2}{23243}=0.0698=\approx 0.07(7 \%) \\
& =\frac{663.62+173.1}{23243}=0.0698=\approx 0.035(3.5 \%)
\end{aligned}
$$

It is clear from the above calculations that the return on capital cost decreases from $7 \%$ to $3.5 \%$ for reduction of sunshine by half.

Following Tiwari [15], the annualized cost can be calculated as follows,

$$
\begin{aligned}
& R=P_{\text {Net }} \times\left[\frac{\left(i \times(1+i)^{n}\right)}{\left((1+i)^{n}-1\right)}\right], \text { where }, i=0.04 \text { and } n=30 \\
& R=P_{\text {Net }} \times 0.05783
\end{aligned}
$$

and

$$
P_{\text {Net }}=P+\left\{\begin{array}{l}
{\left[\frac{P_{B}}{(1+i)^{5}}\right]+\left[\frac{P_{B}}{(1+i)^{10}}\right]+\left[\frac{P_{B}}{(1+i)^{15}}\right]+} \\
{\left[\frac{P_{B}}{(1+i)^{20}}\right]+\left[\frac{P_{B}}{(1+i)^{25}}\right]-\left[\frac{S}{(1+i)^{30}}\right]}
\end{array}\right\}
$$

where, $P_{B}$ is present cost of battery and $i$ is interest rate and $n$ is life of the SAPV system in years.

Annualized cost $=23243.33 \times 0.0578=$ USD $1847.1(11 \mathrm{~b})$

By using the value of Eq. (5a), the electrical cost $/ \mathrm{kWh}=$ USD $1847.1 /(44.04 \times 300)=0.14 \mathrm{USD} / \mathrm{kWh}$

At actual electrical load of the solar energy park i.e. $23.52 \mathrm{kWh}$ (Table 1), then

The electrical cost/kWh will be $=\mathrm{USD} 1847.1 /(23.52 \times 300)=0.26 \mathrm{USD} / \mathrm{kWh}$

(b) Assuming life of the System $=40$ years

$\mathrm{P}_{\mathrm{Net}}=19936.33+4031.0476=\mathrm{USD} 32955$

Return on capital $=0.0656=6.56 \%$

Annualized cost $=$ USD $32955 \times 0.0505234=$ USD 1663.7
The electrical cost $/ \mathrm{kWh}$ from SAPV

$=\operatorname{USD} 1663.7 /(44.04) \times 300)=0.125 \mathrm{USD} / \mathrm{kWh}$

At actual electrical load of the solar energy park i.e. $23.52 \mathrm{kWh}$ (Table 1)

The electrical cost/kWh from SAPV will be $=\mathrm{USD} 1663.7 /(23.52 \times 300)=0.233 \mathrm{USD} / \mathrm{kWh}$

(c) Assuming life of the system $=50$ years

$\mathrm{P}_{\mathrm{Net}}=19936.33+4305.4034=\mathrm{USD} 33331.3$

Return on capital $=0.0649059=6.49 \%$

Annualized cost $=$ USD $33331.3 \times 0.0465502=\mathrm{USD}$ 1551.5

The electrical cost $/ \mathrm{kWh}$ from SAPV

$=\operatorname{USD} 1551.5 /(44.04 \times 300)=0.22 \mathrm{USD} / \mathrm{kWh}$

At actual electrical load of the solar energy park ie 23.52 kWh (Table 1)

The electrical cost/kWh from SAPV

$=\operatorname{USD} 1551.5 /(23.52 \times 300)=0.44 \mathrm{USD} / \mathrm{kWh}$

It is clear that an annualized cost decreases from USD 1847.1 to USD 1551.5 with increase of life of SAPV system by 20 years.

\subsection{Carbon Credit on National Level by SAPV System}

There are 602 Districts in India based on 2005 statistics and as per 2001 census there are approximately 639000 villages. There are 127800 villages in India each having more 1000 population. Presuming one SAPV system is built to be the nucleus of the village activities in each of such village

From Eq. (7b) for twelve sunshine hours, carbon credit earned from all these villages per annum will be,

Annual Carbon credits $=127800 \times$ Rs. $13479.5=$ Rs 1722680000

= Rs 1722.68 million (USD 4.33 million)

From Table 2, one can evaluate,

Capital cost of installing 127800 SAPV systems $=127800$ $\times 19936.38 \times 54.75$

$=$ Rs 13, 9495 million $=$ USD 3492.5 million

From Eq. (5b), one gets,

Table 2. Cost of the SAPV System Installed in the Solar Park

\begin{tabular}{|c|c|c|c|c|}
\hline S. No. & Name of the Component & Number of Components & Unit Cost in USD & Total Cost \\
\hline \hline 1 & CEL Module & 32 & 349.9 & 11196.8 \\
\hline 2 & SIEMENS Module & 34 & 398.7 & 37.4 \\
\hline 3 & Charge Controller & 1 & 149.8 & 13555.8 \\
\hline 4 & Battery Bank & 1 & 149.8 & 1797.6 \\
\hline 5 & AC/DC Inverter & 1 & 624.9 & 624.9 \\
\hline 6 & Frame \& Box & & 27362.3 \\
\hline
\end{tabular}


Total power produced $=13.212 \times 127800 \mathrm{MWh}=$ 1688493.6 MWh

This is equivalent to Rs 9286.71 million (USD 232.3 million) worth of electricity.

If in the first stage SAPV system are installed on each district head quarter of the country.

The capital cost of SAPV system $=602 \times 19936.38=$ USD 15.88 million (Rs 657.093 million)

Total carbon credits earned by such systems $=$ Rs 13479.5 $\times 602=$ Rs 8114659.00

Value of total electricity generated by such systems

$=$ Rs. $13212 \times 602 \times 5.5$

$=$ Rs. 43.75 million

$=$ USD 1.098 million

\subsection{Effect of Initial Cost}

Fig. (6) shows the expected variation of capital cost with year. This indicates that the initial cost of installation of SAPV will decrease and will become $1 / 4$ th in the year 2020 . Variation in initial cost will have no effect on the carbon credits earned by a SAPV system. However the return on capital will vary proportionately. The cost of SAPV systems have been estimated in 2003 to vary from USD 6187 to USD
8937 [16]. It must have come down further as illustrated in the Fig. (6). Return on capital cost has been calculated taking capital cost per kWp of the SAPV system to be USD 4128, USD 5500, USD 6187 and USD 6875. Returns on capital cost so calculated have been given in Table 3. From this table one can observe that the return on capital cost with and without carbon credits are 9.9 and 8.36 respectively for initial investment of USD $4812.5 / \mathrm{kWp}$.

\section{CONCLUSION}

This paper presents an analysis of carbon credit earning by the solar energy systems installed at Solar Energy Park (SEP), IIT Delhi, New Delhi, India. The solar energy park is having a mud house, various hybrid photovoltaic thermal (PV/T) systems with stand alone photovoltaic (SAPV) power supply. The computation of the carbon credit earned by Solar Energy Park as per the norms of the Kyoto Protocol under New Delhi climate condition has also been carried out.

Following conclusions have been drawn:

(i) $\mathrm{CO} 2$ credit earned by solar energy park (SEP) at IIT Delhi is USD 407.2 and USD 230 for twelve and six sunshine hour respectively

(ii) The cost of power generated by the SAPV system is USD $0.14 / \mathrm{kWh}$, USD 0.125 , USD 0.116 for life cycle

Table 3. Variation in Return on Capital Cost with Variation in Initial Cost

\begin{tabular}{|c|c|c|c|}
\hline S. No. & Capital Cost/kWp in USD & Return on Capital Without Carbon Credits \% & Return on Capital with Carbon Credits \% \\
\hline \hline 1 & 4128 & 8.36 & 9.90 \\
\hline 2 & 5500 & 7.49 & 8.88 \\
\hline 3 & 6187 & 6.79 & 8.05 \\
\hline 4 & 6875 & 6.21 & 7.36 \\
\hline 5 & 7469 (present value) & 5.71 & 6.76 \\
\hline
\end{tabular}

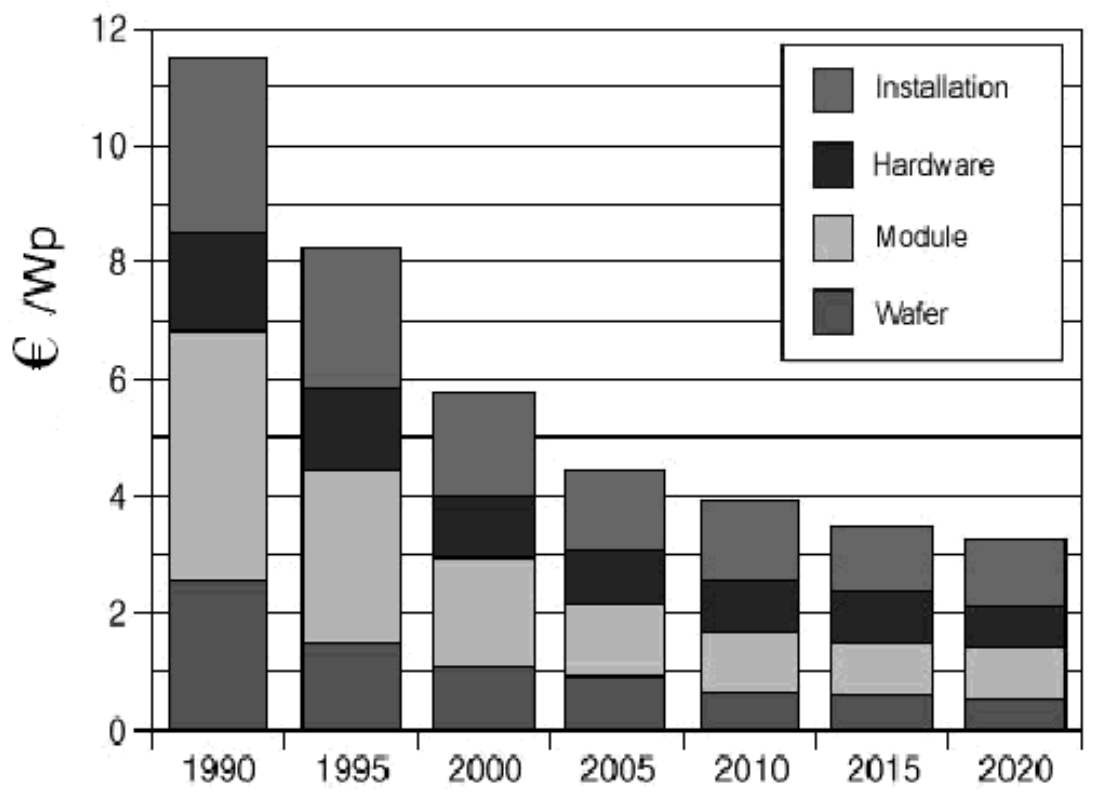

Fig. (6). Capital cost of SAPV systems over time [17]. 
Table 4. Variation in Power Produced, Carbon Credits Earned and Return on Capital with Variation in Solar Intensity and Number of Clear Days in a Year

\begin{tabular}{|c|c|c|c|c|c|c|c|c|}
\hline S. No. & $\begin{array}{l}\text { Solar In- } \\
\text { tensity } \\
\text { W/m }\end{array}$ & $\begin{array}{c}\text { No of } \\
\text { Clear } \\
\text { Days } \\
\text { in a } \\
\text { Year }\end{array}$ & $\begin{array}{l}\text { Power } \\
\text { Produced } \\
\text { MWh/ } \\
\text { Annum }\end{array}$ & $\begin{array}{c}\text { Carbon } \\
\text { Credits } \\
\text { Earned/ } \\
\text { Annum } \\
\text { USD }\end{array}$ & $\begin{array}{c}\text { Return on } \\
\text { Capital \% } \\
\text { Life = 30 Yrs } \\
\text { Capital Cost }= \\
\text { USD } 7469 \text { per } \\
\text { kWp }\end{array}$ & $\begin{array}{c}\text { Return on Capital \% } \\
\text { Life }=40 \text { Yrs } \\
\text { Capital Cost }=\text { USD } \\
7469 \text { per } \mathrm{kWp}\end{array}$ & $\begin{array}{c}\text { Return on Capi- } \\
\text { tal \% } \\
\text { Life }=50 \text { Yrs } \\
\text { Capital Cost }= \\
\text { USD } 7469 \text { per } \\
\text { kWp }\end{array}$ & $\begin{array}{c}\text { Return on Capital \% } \\
\text { Life = 30 Yrs } \\
\text { Capital Cost }=\text { USD } \\
4812 \text { per } \mathrm{kWp}\end{array}$ \\
\hline 1 & 700 & 300 & 8.397 & 215.2 & 4.30 & 4.13 & 4.13 & 6.3 \\
\hline 2 & 700 & 250 & 6.998 & 179.3 & 3.59 & 3.48 . & 3.44 & 5.25 \\
\hline 3 & 700 & 200 & 5.598 & 143.4 & 2.87 & 2.78 & 2.75 & 4.2 \\
\hline 4 & 500 & 300 & 5.998 & 153.7 & 3.07 & 2.95 & 2.95 & 4.5 \\
\hline 5 & 500 & 250 & 4.998 & 128.0 & 2.56 & 2.46 & 2.46 & 3.75 \\
\hline 6 & 500 & 200 & 3.998 & 102.4 & 2.05 & 1.96 & 1.96 & 3.0 \\
\hline 7 & 350 & 300 & 4.199 & 107.6 & 2.15 & 2.09 & 2.06 & 3.15 \\
\hline 8 & 350 & 250 & 3.499 & 89.6 & 1.79 & 1.74 & 1.72 & 2.62 \\
\hline 9 & 350 & 200 & 2.799 & 71.7 & 1.43 & 1.39 & 1.38 & 2.10 \\
\hline
\end{tabular}

\section{of 30,40 and 50 years respectively}

(iii) The overall annual thermal and exergy energy for Solar Energy Park is 106, 556.00 kWh (106.5 MWh) and $2692 \mathrm{kWh}(2.692 \mathrm{MWh})$ and

(iv) One such Solar Energy Park is build in each district/ block/Village in the country then the total carbon credits earned by such systems is Rs 8.11 million (USD 0.2 million) and value of total electricity generated by such systems is Rs. 43.75 million (USD 1.1 million).

\section{REFERENCES}

[1] Kalshian, R. Energy versus emissions: The big challenge of the new millennium. By Info Change News and Features. www.infochangeindia.org/agenda5 01.jsp (accessed July 12, 2008).

[2] International Energy Agency. http://www.iea.org/Textbase/stats/ind ex. asp (accessed July 10, 2008).

[3] Pathak, B.S. India should look at renewable energy as a sustainable solution. Sardar Patel Renewable Energy Research Institute. http://www.projectsmonitor.com/detailnews.asp?newsid=7782 (accessed August 01, 2008).

[4] Prakash, O.; Chel, A.; Tiwari, G.N. In Solar Radiation and Day Lighting (SOLARIS 2007), Proceedings of the $3^{\text {rd }}$ International Conference, New Delhi, India, February 8 -10, 2007; Dube, S.K.; Muneer, T.; Tiwari, G.N., Eds.; Anamaya Publishers: New Delhi, India, 2008; Vol. II, pp. 87-101.

[5] European Climate Exchange. www.europeanclimateexchange.com (accessed July 03, 2008).
[6] Barnwal, P.; Tiwari, A. Performance analysis of a hybrid photovoltaic thermal $(\mathrm{PV} / \mathrm{T})$ integrated greenhouse air heater and dryer. Int. J. Agric. Res., 2008, 3(2), 110-120.

[7] Sujata, N.; Tiwari, A. Performance evaluation of an hybrid photovoltaic thermal (PV/T) greenhouse system. Int. J. Agric. Res., 2007, 2(3), 211-226.

[8] Tiwari, A.; Sodha, M.S. Parametric study of various configurations of hybrid PV/thermal air collector: Experimental validation of theoretical model. Solar Energy Materials and Solar Cells, 2007, 91, 17-28.

[9] Tiwari, G.N.; Tiwari, A.K. Solar distillation practice for water desalination systems, $1^{\text {st }}$ ed.; Anamaya Publishers: New Delhi, India, 2007.

[10] Dubey, S.; Tiwari, G.N. Life cycle cost analysis and carbon credit earned by hybrid PV/T solar water heater for Delhi climatic conditions. Open Environ. J., 2008, 2, 15-25.

[11] Huang, B.J.; Lin, T.H.; Hung, W.C.; Sun, F.S. Performance evaluation of solar photovoltaic/thermal systems. Solar Energy, 2001, 70, 443-448.

[12] Petela, R. Exergy of undiluted thermal radiation. Solar Energy, 2003, 86, 241-247.

[13] Dincer, I. The role of exergy in energy policy making. Energy Policy 2002, 30, 137-149.

[14] Dincer, I.; Sahin, A.Z. A new model for thermodynamic analysis of a drying process. Int. J. Heat Mass Transfer, 2004, 47, 645-652.

[15] Tiwari, G.N. Solar Energy, $2^{\text {nd }}$ ed.; Narosa Publishing House: New Delhi, India, 2004.

[16] Photovoltaic system economics, Economics and Environmental Impacts. http:/www.pvresources.com/en/economics.php (accessed June 21,2008 ).

[17] Research Institute for Sustainable Energy, Australia. www.rise.org. au (accessed July $05, \mathbf{2 0 0 8}$ ). 